
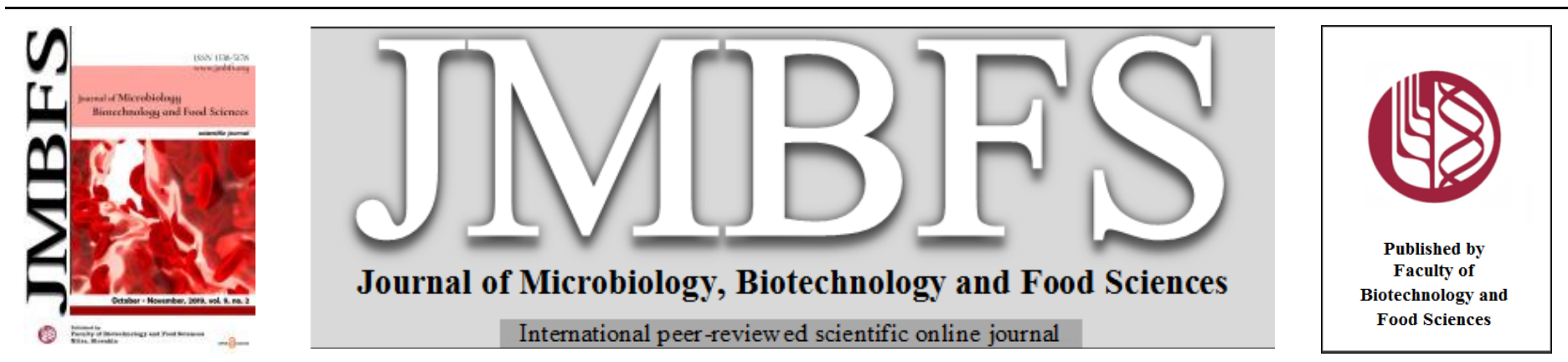

\title{
TECHNOLOGICAL PROPERTIES OF POTENTIAL PROBIOTIC LACTOBACILLUS STRAINS ISOLATED FROM TRADITIONAL FERMENTING GREEN OLIVE
}

\section{Houssam Abouloifa $*^{1}$, Yahya Rokni ${ }^{l}$, Reda Bellaouchi ${ }^{l}$, Ismail Hasnaoui ${ }^{l}$, Sara Gaamouche ${ }^{l}$, Nabil Ghabbour $^{l}$, Jabir Chaoui $^{l}$, Milena Brasca ${ }^{2}$, Salwa Karboune ${ }^{3}$, Riadh Ben Salah $^{4}$,Ennouamane Saalaoui ${ }^{1}$, Abdeslam Asehraou ${ }^{1}$}

Address(es): Houssam Abouloifa,

${ }^{1}$ Laboratory of Biochemistry and Biotechnology, Faculty of Sciences, Mohammed Premier University, Oujda 60000, Morocco.

${ }^{2}$ Institute of Sciences of Food Production, National Research Council, Via Celoria 2, 20133, Milan, Italy.

${ }^{3}$ Department of Food Science and Agricultural Chemistry, Macdonald Campus, McGill University 21,111 Lakeshore, Ste Anne de Bellevue, Quebec H9X 3V9, Canada.

${ }^{4}$ Laboratory of Microorganisms and Biomolecules, Centre of Biotechnology of Sfax, BP: 1177, 3018, Tunisia.

*Corresponding author: h.abouloifa@ump.ac.ma

doi: $10.15414 / j m b f s .2020 .9 .5 .884-889$

\section{ARTICLE INFO}

Received 3. 12. 2018

Revised 18. 10. 2019

Accepted 22. 10. 2019

Published 1. 4. 2020

Regular article

open $\partial$ ACCESS

\begin{abstract}
The aim of the present study was to evaluate some technological properties and potential probiotic of 14 Lactobacillus strains isolated from brines of natural fermenting Moroccan Picholine green olive. The brine samples, collected from industrial environments, were analyzed for their Physico-chemical and microbiological properties. The Lactobacillus strains were characterized for their technological and physiological properties. The results obtained showed that the olive brines have an average $\mathrm{pH}$ of 4.32 , an acidity of $0.61 \%$ and chloride contents of $6.42 \%$. LAB and yeasts are the most dominant microorganisms in olive brine samples. The selected Lactobacillus (14 strains) showed low resistance to $\mathrm{pH} 2$ and high resistance to bile salts (up to 2\%), with values ranges from $1.98 \%-4.70 \%$ and $63.12 \%-86.48 \%$, respectively. All the Lactobacillus strains displayed high levels of acidification and can produce $\beta$-glucosidase, protease, and cellulase in large amounts. The diacetyl production is detected in five Lactobacillus strains.
\end{abstract}

Keywords: Lactic acid bacteria, Lactobacillus, Probiotic, Fermentation, Olives

\section{INTRODUCTION}

Table olive is a major fermented product in Mediterranean countries. The International Olive Oil Council estimates the world production of table olive to about 2829500 tones during the 2016/2017 season (IOOC, 2017). The main industrial processes of table olives production include the Spanish style for green olives, the Greek style for black olives, and the Californian style for oxidized black olives (Fernandez et al., 1997).

In Morocco, industrial table green olive processing is mainly based on the Spanish style, obtained with alkali-treatment with sodium hydroxide of olives in a lye solution to eliminate the oleuropein, the main polyphenol responsible for the bitterness of olive fruit (Kailis and Harris, 2007). After debittering, the olives were subject to successive washes to remove residual sodium hydroxide and then brined at $10-12 \%$ of $\mathrm{NaCl}$, where they undergo a natural lactic fermentation (Fernandez et al., 1997, Kailis and Harris, 2007). This spontaneous fermentation process is mainly carried out by lactic acid bacteria, the most dominant microorganisms in olive brine (Fernandez-Diez et al., 1985).

The fermentation environment is characterized by alkaline $\mathrm{pH}$ (due to lye treatment of the olives), high initial salt concentration (10-12\%) and polyphenol contents (i.e. oleuropein and its by-products). Lactic acid bacteria (LAB) should support these stress factors and compete with other microorganisms to succeed in the natural lactic fermentation process of the olives. The biochemical activity of LAB should overcome those of undesirable microorganisms (mainly enterobacteria, Staphylococcus, Bacillus, Propionibacterium, Clostridium, yeasts, and molds) to avoid olive spoilage and foodborne diseases (Fernandez-Diez $\boldsymbol{e t}$ al., 1985). LAB autochthonous to this environment is a good candidate in starter selection for olive fermentation.

LAB to be used as a starter must be easily adapted to the fermentation environment and have non-pathogenic, probiotic and technological characteristics. LAB are known for their capacity of producing antimicrobial substances, sugar polymers, sweeteners, aromatic compounds, vitamins, or useful enzymes, or for their probiotic properties (Bonatsou et al., 2017). The technological characteristics of LAB in table olive have to be survival in brine, production of high amounts of lactic acid during fermentation, tolerance to high $\mathrm{pH}$ and $\mathrm{NaCl}$ values, the production of volatile compounds and specific enzymes, improving the sensorial properties of fermented olives (Bautista-Gallego et al. 2013, Bonatsou et al., 2017). The good evidence of microbial and/or specific enzymes to develop novel biotechnological methods in place of chemical treatment of the green table olives (De Leonardis et al., 2015). The LAB to be used in this biotechnological process must meet technological properties, health promotion, and disease prevention. Previous studies showed that the microbiota of fermented olives exhibited specific probiotic properties (Martins et al., 2013), thus natural fermented green olives are good matrices to develop autochthonous starters for controlled fermentation of green olives with probiotic properties.

The main objective of this work is the characterization of the technological properties of potential probiotic Lactobacillus strains isolated from natural fermenting green brines.

\section{MATERIAL AND METHODS}

\section{Samples Collection}

Seven brine samples of natural fermenting non-alkali-treated green olive collected aseptically from the industrial environment from enterprise TRIFFA, were transported at $4^{\circ} \mathrm{C}$ for their Physico-chemical and microbiological analyses.

\section{Physico-chemical Analyses}

The $\mathrm{pH}$ of brine samples was measured, using a $\mathrm{pH}$ meter (VWR Symphony $\underline{\mathrm{SB} 70 \mathrm{P}})$. The titratable acidity of brine samples was determined by titrating 10 $\mathrm{mL}$ of brine with sodium hydroxide $(0.1 \mathrm{~N})$ in the presence of phenolphthalein. The results of titratable acidity were expressed in percent of lactic acid $(\mathrm{g} / 100$ $\mathrm{mL}$ ). Chlorides contents in brine were determined as follows: to $10 \mathrm{ml}$ of brine samples we added two drops of potassium chromate $(0.1 \mathrm{~N})$, then this solution was titrated with $(0.1 \mathrm{~N})$ silver nitrate solution $(\mathrm{AgNO} 3)$ until the appearance of the persistent brick red color. The chlorides were expressed as a percentage of $\mathrm{NaCl}$ (g/100 mL of brine). All the Physico-chemical analyses were performed in triplicate. 


\section{Microbiological Analyzes}

The microbiological analyses of olive brine, made in duplicate, included an enumeration of total aerobic mesophilic flora (FMAT), enterobacteriaceae, spore-forming Bacteria, yeasts and molds, and lactic acid bacteria (LAB). Brine samples were serially diluted in sterile saline solutions $(9 \mathrm{~g} / \mathrm{L} \mathrm{of} \mathrm{NaCl})$ and then $0.1 \mathrm{~mL}$ of each dilution was plated on a specific medium of each microorganism The FMAT were enumerated on the Plate Count Agar (PCA) (BIOKAR, FRANCE) after $48 \mathrm{~h}$ of incubation at $37^{\circ} \mathrm{C}$. The spores of Bacillus were enumerated, in brine samples heated at $80^{\circ} \mathrm{C} / 10 \mathrm{~min}$, using PCA and incubated at $37^{\circ} \mathrm{C} 48 \mathrm{~h}$. The enterobacteriaceae were enumerated on the Mac Conkey agar (BIOKAR, FRANCE) after $48 \mathrm{~h}$ of incubation at $37^{\circ} \mathrm{C}$. Yeasts and molds were enumerated on Potato-Dextrose-Agar (PDA) (BIOKAR, FRANCE) after 48-72 h of incubation at $25^{\circ} \mathrm{C}$. Lactic acid bacteria were enumerated on de Man Rogosa and Sharpe agar (MRS) (BIOKAR, FRANCE), supplemented with cycloheximide $(0.01 \%)$, after 48 to $72 \mathrm{~h}$ of incubation at $37^{\circ} \mathrm{C}$.

\section{Lactobacillus Strains and Growth Conditions}

14 LAB strains used in this work were isolated from the brine samples of natura fermenting green olives, and selected for their high antifungal activity, and characterized for their probiotic and safety properties (Abouloifa et al., 2019). They were identified by the $16 \mathrm{~S}$ rRNA sequencing method using the universal primers $27 \mathrm{~F}$ and 1492R (data not shown), and they included Lactobacillus brevis (5 strains), Lactobacillus pentosus (2 strains) and Lactobacillus plantarum (7 strains), and the accession numbers for their 16S rRNA gene sequences are NR 044704.2, NR 029133.1, and NR 104573.1, respectively. These strains were maintained in $20 \%$ glycerol $(\mathrm{v} / \mathrm{v})$ at $-80^{\circ} \mathrm{C}$, they were routinely reactivated in de Man Rogosa and Sharpe (MRS) broth (BIOKAR, FRANCE) at $37^{\circ} \mathrm{C}$ for 18 $\mathrm{h}$ before use.

\section{Physiological Characterization of Lactobacillus Strains}

The 14 Lactobacillus strains were characterized physiologically by testing their growth capacity at different temperatures $\left(15,30,37\right.$ and $\left.45^{\circ} \mathrm{C}\right)$, at different $\mathrm{pHs}$ (4, 6, 7 and 9) and different concentrations of $\mathrm{NaCl}(2,4,6,8,10$ and 12\%). The growth tests (temperature, $\mathrm{pH}$ and $\mathrm{NaCl}$ ) were performed in MRS broth inoculated with overnight cultures and incubated at $37^{\circ} \mathrm{C}$ for $24 \mathrm{~h}$ for $\mathrm{pH}$ and $\mathrm{NaCl}$. The presence of biomass growth in MRS broth indicated the tolerance to the parameter studied.

\section{Resistance to Bile Salts}

The 14 Lactobacillus strains were studied for their resistance to higher concentrations of bile salts. $0.1 \mathrm{~mL}$ of the overnight culture was inoculated in 10 $\mathrm{mL}$ of MRS broth containing bile salts at different concentrations $(0.3,0.5,1$ and $2 \%, w / v)$. After incubation at $37^{\circ} \mathrm{C}$ for $48 \mathrm{~h}$, the biomass of the strains was evaluated by measuring the absorbance (OD) at $600 \mathrm{~nm}$. The MRS without bile salts was used as a control in this test. All the tests were performed in triplicate. The resistance (\%) to bile salts was calculated as follows:

$$
\% \text { Resistance }=\frac{\text { OD in MRS broth with bile salts }(0.3,0.5,1 \text { and } 2 \%)}{\text { OD in MRS broth without bile salts }} \times 100
$$

\section{Resistance to Acid pH}

The resistance to the acid $\mathrm{pH}$ was studied by inoculating $1 \%$ of overnigh cultures, of the 14 Lactobacillus strains, in $10 \mathrm{~mL}$ of MRS broth adjusted with $\mathrm{HCl}(4 \mathrm{M})$ to different $\mathrm{pH}$ values $\left(2,2.5\right.$ and 3). After incubation at $37^{\circ} \mathrm{C}$ for $48 \mathrm{~h}$, the biomass of the strains was obtained by measuring the absorbance at $600 \mathrm{~nm}$. The normal MRS $(\mathrm{pH}=6.5)$ was used as a control in this test. All the experiments were performed in triplicate. The resistance $(\%)$ to the $\mathrm{pH}$ was calculated as follows:

$$
\% \text { Resistance }=\frac{\text { OD in MRS broth with } \mathrm{pH}(2,2.5 \text { and } 3)}{\text { OD in MRS broth normal }(\mathrm{pH}=6.5)} \times 100
$$

\section{Acidification Activity}

The acidification activity of the Lactobacillus strains was evaluated by measuring the $\mathrm{pH}$ change of the medium during their culture. The culture was performed in MRS broth $(50 \mathrm{ml})$, inoculated with $1 \%$ of an overnight culture of the Lactobacillus strains, and incubated at $37^{\circ} \mathrm{C}$. The $\mathrm{pH}$ was measured at $0,12,24$, 36,48 , and $72 \mathrm{~h}$ of incubation using a calibrated $\mathrm{pH}$ meter type VWR Symphony $\underline{\mathrm{SB} 70 \mathrm{P}}$. The $\mathrm{pH}$ was measured in triplicate.

\section{Diacetyl Production}

The diacetyl production capacity of the Lactobacillus strains was determined according to the method of King (1948). Overnight cultures of Lactobacillus strains were inoculated $(1 \%)$ in $10 \mathrm{~mL}$ of UHT milk and incubated at $37^{\circ} \mathrm{C}$ for 24 h. One milliliter of each Lactobacillus culture was combined with $0.5 \mathrm{~mL}$ of $\alpha$ naphthol (1\% w/v) (Sigma-Aldrich, USA) and KOH (16\% w/v) (Sigma-Aldrich USA) and then incubated at $37^{\circ} \mathrm{C}$ for $10 \mathrm{~min}$. Diacetyl production is indicated by the formation of a red ring at the top of the culture in the tube. All the assays were performed in triplicate.

\section{Enzymatic Characterization of Lactobacillus Strains}

\section{B-glucosidase Activity}

The $\beta$-glucosidase activity was determined according to Ciafardini et al. (1994) Briefly, a volume of $0.2 \mathrm{ml}$ of $0.3 \%$ (w/v, dissolved in N, N-dimethylformamide) of 5-bromo-3-indolyl- $\beta$-D-glucoside (X-Gluc) (Sigma-Aldrich, USA) was spread onto MRS agar, and then drop-inoculated by dropping $5 \mu$ of overnight cultures of Lactobacillus strains. The assays were incubated at $37^{\circ} \mathrm{C}$ for 7 days. The positive strains producing $\beta$-glucosidase were identified as blue-colored colonies.

\section{Proteolytic Activity}

The proteolytic activity of the Lactobacillus strains was evaluated according to Phyu et al., (2015), on skim milk agar containing: Casein $(5 \mathrm{~g} / \mathrm{L})$, yeast extract $(2.5 \mathrm{~g} / \mathrm{L})$, dextrose $(1 \mathrm{~g} / \mathrm{L})$, skim milk powder $(28 \mathrm{~g} / \mathrm{L})$ and agar $(20 / \mathrm{L})$. Overnight cultures of the Lactobacillus strains were spot-inoculated on the medium and incubated for $48 \mathrm{~h}$ at $37^{\circ} \mathrm{C}$. Proteolytic strains displayed clear zones around colonies.

\section{Lipolytic Activity}

The lipolytic activity of the Lactobacillus strains was determined on a culture medium composed of: peptone $(10 \mathrm{~g} / \mathrm{L}), \mathrm{CaCl} 2,2 \mathrm{H} 2 \mathrm{O}(0.1 \mathrm{~g} / \mathrm{L})$, Tween 80 $(1 \mathrm{~mL} / \mathrm{L})$ and agar $(20 \mathrm{~g} / \mathrm{L})$, according to the method described by Tanasupawat et al. (2015). Overnight cultures of the Lactobacillus strains were spot-inoculated on the medium and incubated at $37^{\circ} \mathrm{C}$ for $48 \mathrm{~h}$. Lipolytic activity causes opaque zones around the colonies.

\section{Amylolytic Activity}

The amylolytic activity of the Lactobacillus strains was evaluated by measuring their ability to hydrolyze starch in the agar medium. Overnight cultures of the Lactobacillus strains were spot-inoculated onto MRS agar supplemented with $1 \%$ $(\mathrm{w} / \mathrm{v})$ of potato starch and incubated at $37^{\circ} \mathrm{C}$ for $48 \mathrm{~h}$. After incubation, the cultures were flooded with iodine solution $(4 \%, \mathrm{v} / \mathrm{v})$. A clear zone around the colonies indicates the production of the amylase enzyme.

\section{Cellulolytic Activity}

The cellulolytic activity of the Lactobacillus strains was evaluated according to the method of Yang et al.(2014). Overnight cultures of the Lactobacillus strains were inoculated on MRS agar supplemented with 1\% (w/v) Carboxy Methyl Cellulose (CMC). The MRS agar was incubated at $37^{\circ} \mathrm{C}$ for $48 \mathrm{~h}$. After incubation, the cultures (MRS-CMC plates) were flooded with $1 \%(w / v)$ Congo red for $15-20 \mathrm{~min}$, then bleached with $1 \mathrm{M} \mathrm{NaCl}$ for $15-20 \mathrm{~min}$ and allowed to stand for 15 minutes at room temperature. Clear zones obtained around colonies indicated cellulolytic activity.

\section{Statistical Analysis}

The Student-Newman-Keuls (S-N-K) comparison test was used to identify the group of means by the one-way analysis of variance (ANOVA), followed by means comparisons. A p-value $<0.05$ was considered statistically significant. The results are represented by means of values \pm standard deviation.

\section{RESULTS AND DISCUSSION}

\section{Physico-chemical and Microbiological Analyses of the Olive Brine}

Table 1 shows the results of the physicà-chemical analyses of the natural fermenting olive brine samples. The results showed value ranges of 4.3- 4.4 for $\mathrm{pH}, 0.5-0.67 \%$ (w/v of Lactic acid) for free acidity, and $6.14-6.72 \%(\mathrm{w} / \mathrm{v})$ for chloride contents. These parameters values fall within the ranges tolerable by lactic acid bacteria (LAB).

The microbiological properties of the seven samples were evaluated, and the results are reported in Table 2. The microbial load ranged between 8.07 and 8.52 $\log \mathrm{CFU} / \mathrm{mL}$ for FMAT, 6.48 and $8.06 \log \mathrm{CFU} / \mathrm{mL}$ for yeasts and molds, and 8.04 and $8.96 \log \mathrm{CFU} / \mathrm{mL}$ for LAB. On the other hand, enterobacteria, staphylococci as well as aerobic spores forming bacteria (Bacillus) were not detected in all the brine samples, indicating their good hygienic quality. The microbiological analyses allowed us to isolate 104 isolates of LAB from the seven olive brine samples analyzed. 
Table 1 Physico-chemical properties of the fermenting green olive brine samples

\begin{tabular}{|c|c|c|c|}
\hline Brine Samples & $\mathrm{pH}$ & Titratable acidity $\%$ & Chloride \% \\
\hline E1 & $4.4^{\mathrm{a}} \pm 0.00$ & $0.55^{\mathrm{c}} \pm 0.01$ & $6.16^{\mathrm{c}} \pm 0.02$ \\
\hline E2 & $4.3^{\mathrm{b}} \pm 0.01$ & $0.67^{\mathrm{a}} \pm 0.01$ & $6.16^{\mathrm{c}} \pm 0.02$ \\
\hline E3 & $4.4^{\mathrm{a}} \pm 0.00$ & $0.64^{\mathrm{b}} \pm 0.01$ & $6.45^{\mathrm{b}} \pm 0.06$ \\
\hline $\mathrm{E} 4$ & $4.3^{\mathrm{b}} \pm 0.01$ & $0.63^{\mathrm{b}} \pm 0.00$ & $6.45^{\mathrm{b}} \pm 0.06$ \\
\hline E5 & $4.3^{\mathrm{b}} \pm 0.00$ & $0.63^{\mathrm{b}} \pm 0.00$ & $6.45^{\mathrm{b}} \pm 0.06$ \\
\hline E6 & $4.4^{\mathrm{a}} \pm 0.01$ & $0.64^{\mathrm{b}} \pm 0.01$ & $6.69^{\mathrm{a}} \pm 0.04$ \\
\hline E7 & $4.3^{\mathrm{b}} \pm 0.01$ & $0.64^{\mathrm{b}} \pm 0.01$ & $6.69^{\mathrm{a}} \pm 0.04$ \\
\hline
\end{tabular}

Values are mean \pm standard error of triplicates.

${ }^{\mathrm{a}-\mathrm{c}}$ Means in same column of each parameter with different lower case letters differed significantly $(\mathrm{p}<0.05)$.

The LAB dominated in all samples of olive brines. LAB is the main microorganisms responsible for the brine acidification by the production of lactic acid from fermentable substrates (Bonatsou et al., 2017). The low $\mathrm{pH}$ values obtained $(\mathrm{pH}<4.5)$, may provide microbiological stability of fermented olives. However, these conditions may encourage the growth of yeasts and molds, leading to the development of olive spoilage, mainly gas-pockets (Asehraou $\boldsymbol{e t}$ al., 2000). The chloride contents can strongly inhibit some microorganisms involved in olive spoilage, especially enterobacteria, without affecting LAB (Rokni et al., 2015). These results are similar to those obtained on Spanish-style green table olives (Lucena-Padros et al., 2014).

The absence of these microorganisms is probably due to a low $\mathrm{pH}$, high acidity and chloride values obtained in brine samples. It may be due also to the antimicrobial compounds commonly produced by LAB, such as organic acids, bacteriocins, peptides, $\mathrm{H} 2 \mathrm{O} 2$, etc (Henning et al. 2015). These antimicrobial compounds are known for their inhibitory effect against pathogens, such as enterobacteriaceae (Hurtado et al., 2008). In addition to the improvement of the hygienic quality of the olives, LAB is highly desired in olive brines to improve the organoleptic attributes (Asehraou et al., 1993), and to reduce the bloater spoilage incidence in fermented olives (Ghabbour et al., 2016). LAB and yeasts are the most dominant microflora in brine samples. These results confirm those obtained by other authors (Fernandez et al., 1997, Pereira et al., 2008). One of the roles of yeasts in olive fermentation is to synthesize nutrients essential to improve the growth of LAB (Arroyo-López et al., 2008).

Table 2 Microbiological properties of the fermenting green olive brine samples

\begin{tabular}{|c|c|c|c|c|}
\hline \multirow{2}{*}{ Brine Samples } & \multicolumn{4}{|l|}{$\log$ CFU/mL } \\
\hline & FMAT & Enterob. & Staph. & Bacillus \\
\hline E1 & $8.36^{\mathrm{bc}} \pm 0.09$ & ND & ND & ND \\
\hline E2 & $8.52^{\mathrm{a}} \pm 0.06$ & ND & ND & ND \\
\hline E3 & $8.41^{\mathrm{b}} \pm 0.03$ & ND & ND & ND \\
\hline E4 & $8.32^{\mathrm{c}} \pm 0.02$ & ND & ND & ND \\
\hline E5 & $8.50^{\mathrm{a}} \pm 0.04$ & ND & ND & ND \\
\hline E6 & $8.07^{\mathrm{e}} \pm 0.04$ & ND & ND & $\mathrm{ND}$ \\
\hline E7 & $8.21^{\mathrm{d}} \pm 0.05$ & ND & ND & ND \\
\hline
\end{tabular}

Legends: FMAT: total aerobic mesophilic flora, Enterob.: Enterobacteriaceae, Staph: Staphylococcus, Y\&M : Yeasts and Molds, LAB: lactic acid bacteria, ND not detected

Values are mean \pm standard error of triplicates.

${ }^{\mathrm{a}-\mathrm{e}}$ Means in same column of each parameter with different lower case letters differed significantly $(\mathrm{p}<0.05)$

\section{Physiological Characterization of Lactobacillus Strains}

All the Lactobacillus strains showed a growth capacity at $30^{\circ} \mathrm{C}, 37^{\circ} \mathrm{C}$ and $45^{\circ} \mathrm{C}$, which may be due to their natural selection during olive fermentation in the temperate region, with annual temperatures between $15^{\circ} \mathrm{C}$ and $44^{\circ} \mathrm{C}$ (east of Morocco). All the strains showed a wide $\mathrm{pH}$ range of growth, which may be due to their isolation from green olives treated with alkaline solutions. All the strains showed their tolerance to up to $12 \%$ of $\mathrm{NaCl}$, which may be due to their selection during the first days of brining, characterized by high $\mathrm{NaCl}$ contents $(10-12 \%$, w/v), widely used in olive industry to avoid spoilage.

\section{Resistance of Lactobacillus Strains to Acid pH and Bile Salts}

The resistance of 14 Lactobacillus strains to acid conditions close to those of the stomach was carried out by culture in MRS adjusted to different initial pHs and higher bile salts concentrations for $48 \mathrm{~h}$ at $37^{\circ} \mathrm{C}$. The results obtained are shown in Table 3. All strains of Lactobacillus could grow at $\mathrm{pH}$ acid and bile salt (acid $\mathrm{pH}$ and in presence of high bile salts contents).

The resistance values of the Lactobacillus strain ranges of $2.97 \%-7.61 \%, 2.63 \%$ $6.74 \%$ and $1.98 \%-4.70 \%$ to $\mathrm{pH} 3, \mathrm{pH} 2.5$ and $\mathrm{pH} 2$, respectively. The resistance of all Lactobacillus strains to bile salts concentrations ranged between $79.36 \%$ $97.26 \%, 78.83 \%-95.28 \%, 74.50 \%-92.44 \%$ and $63.12 \%-86.48 \%$ for $0.3,5,1$ and $2 \%$ of bile salts, respectively. All the Lactobacillus strains showed low resistance to $\mathrm{pH}$ 2. With respect to the bile salts, all strains showed high resistance up to $2 \%$ of bile salts. The resistance values, to different $\mathrm{pH}$ and bile salt concentrations, obtained for all the Lactobacillus strains, are mostly not significantly $(\mathrm{p}<0.05)$ different between the three species (L. brevis, L. pentosus and L. plantarum).

The L. brevis $\mathrm{S} 82$, L. pentosus $\mathrm{S} 42$, and L. plantarum $\mathrm{S} 72$ demonstrated a good resistance to acid $\mathrm{pH}$; while L. brevis $\mathrm{S} 63$, L. pentosus $\mathrm{S} 75$, and L. plantarum $\mathrm{S} 71$ showed high resistance to bile salt. This finding indicates that the resistance to $\mathrm{pH}$ and bile salts concentrations seems to be strain-dependent.

The resistance to acid $\mathrm{pH}$ and bile salts are now considered the basic criteria of screening for potentially probiotic strains (Dunnel et $\boldsymbol{a l}$., 1999). Resistance to $0.3 \%$ of bile salts is considered as the main criterion in the selection of probiotics (Gilliland et al., 1984). Probiotics must be able to survive in the human gastrointestinal tract and exercise their biochemical and physiological activities. LAB strains, isolated from naturally fermenting Portuguese and Italian-green olive varieties, were found to tolerate bile salts $(0.3 \%)$ and low $\mathrm{pH}$ (Bevilacqua et al., 2010, Peres et al., 2014). It should be emphasized that the Lactobacillus strains tolerated higher concentrations $(2 \%)$ of bile salts, known for its antimicrobial activity mainly against Gram-positive bacteria (Hofmann and Eckmann, 2006). The high tolerance of these strains to bile salts may be due to their production of bio-protecting and/or hydrolyzing agents against this detergent (Horackova et al., 2018). The acidity ( $\mathrm{pH} 2.5$ to 3.5 ) of gastric secretions and bile salts destroyed the majority of bacteria that enter the gastrointestinal tract (Holzapfel et al., 1998). All of these Lactobacillus strains are resistant to high bile concentration and low $\mathrm{pH}$, indicating their ability to survive in the gastrointestinal tract. These findings allow us to select these Lactobacillus strains as potential candidates in deep studies for probiotic applications.

\section{Acidification Activity}

The results of the acidification activity of the Lactobacillus strains obtained after $12,24,36,48$ and $72 \mathrm{~h}$ of culture in MRS broth at $37^{\circ} \mathrm{C}$ are reported in table 4 . After $12 \mathrm{~h}$ of incubation, all of the Lactobacillus strains showed a low-reduction of $\mathrm{pH}$ from 6.35 to 5.2-5.8. However, a drastic reduction of $\mathrm{pH}$ to 3.8 was obtained after $36 \mathrm{~h}$ of incubation, remaining stable for $72 \mathrm{~h}$, with no significant differenees ( $\mathrm{p}<0.05$ ) between Lactobacillus speeies and strains. While the $\mathrm{pH}$ of the non-inoculated MRS (control) was stable at 6.35 after $72 \mathrm{~h}$ of incubation. All of the Leqtpbacillus strains showed a good acidification capacity, which may

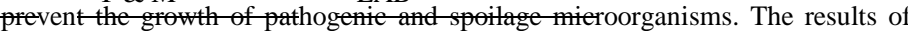
acidificatign tagtipity are similar t96 thos.920btained on LAB strains isolated from Spanish fermenting green olives (Abriouel et al., 2012).

$$
8.06^{\mathrm{a}} \pm 0.08 \quad 8.19^{\mathrm{cd}} \pm 0.03
$$

Diacetyl Production

$$
6.91^{\mathrm{c}} \pm 0.04 \quad 8.23^{\mathrm{c}} \pm 0.02
$$

The results pbtained in this work indicate that 5 Lactobacillus strains (L. brevis S14 and S18, L. pentosus S75, and L. plantarum S49 and S61), out of the 14 Lactobagilgys $s_{ \pm}$rojins, showed theqireqp (2,3-butanedione) is a volatile compound generated from citrate metabolism by certain IGAIB Delgadillo et al., 2012). Diacetyl is known for its antimicrobial action towards

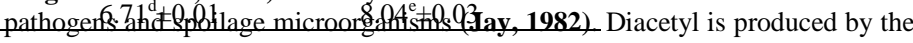
main genera of LAB (Streptococcus, Leuconostoc, Lactobacillus, and Pediococcus) (Jay, 1982). Some Lactobacillus strains, of L. plantarum, $L$. pentosus, L. brevis and L. casei species, were confirmed for their diacetyl production capacity (Chuang and Collins, 1968, Hickey et al., 1983, Phalakornkule and Tanasupawat, 2007, Pan et al., 2014). Diacetyl is highly involved in flavor formation and antimicrobial activity of LAB (Jay, 1982).

\section{Enzymatic Characterization of Lactobacillus Strains}

The enzymatic characterization of Lactobacillus strains was evaluated by the ability to produce different enzymes. The results are reported in table 5. All of Lactobacillus strains showed a blue color after 7 days of incubation at $37^{\circ} \mathrm{C}$, indicating their capacity for the production of $\beta$-glucosidase. All the strains showed high levels of producing $\beta$-glucosidase activity. These results may be due to the natural selection of these Lactobacillus strains in olive brine rich of oleuropein, the major phenolic glucoside of olives. LAB strains producing $\beta$ glucosidase have been isolated from natural fermenting green olives brines of Moroccan, Portuguese, Spanish and Italian olive varieties (Ghabbour et al., 2011, Abriouel et al., 2012, Peres et al., 2014, Tofalo et al., 2014). 
Table 3 Resistance (\%) of Lactobacillus strains to acid $\mathrm{pH}$ and bile salts obtained after $48 \mathrm{~h}$ of incubation at $37^{\circ} \mathrm{C}$

\begin{tabular}{|c|c|c|c|c|c|c|c|}
\hline \multirow{2}{*}{ LAB strains } & \multicolumn{3}{|c|}{$\mathrm{pH}$} & \multicolumn{4}{|c|}{ Bile salts $(\% . \mathrm{w} / \mathrm{v})$} \\
\hline & 2 & 2.5 & 3 & 0.3 & 0.5 & 1 & 2 \\
\hline L.brevis S18 & $3.55^{\mathrm{d}} \pm 0.16$ & $5.44^{\mathrm{d}} \pm 0.25$ & $5.56^{\mathrm{f}} \pm 0.26$ & $85.74^{\mathrm{e}} \pm 3.94$ & $80.42^{\mathrm{ef}} \pm 3.69$ & $74.50^{\mathrm{h}} \pm 3.42$ & $68.59^{\mathrm{fgh}} \pm 1.58$ \\
\hline L. brevis $\mathrm{S} 63$ & $2.92^{\mathrm{f}} \pm 0.03$ & $6.19^{\mathrm{b}} \pm 0.07$ & $6.78^{\mathrm{d}} \pm 0.08$ & $95.71^{\mathrm{abc}} \pm 1.07$ & $89.34^{\mathrm{c}} \pm 1.00$ & $87.65^{\mathrm{bc}} \pm 0.98$ & $86.48^{\mathrm{a}} \pm 0.48$ \\
\hline L. brevis $\mathrm{S} 82$ & $3.69^{\mathrm{c}} \pm 0.02$ & $5.78^{\mathrm{c}} \pm 0.04$ & $7.09^{\mathrm{c}} \pm 0.05$ & $96.25^{\mathrm{ab}} \pm 0.65$ & $90.88^{\mathrm{bc}} \pm 0.61$ & $83.43^{\mathrm{de}} \pm 0.56$ & $82.24^{\mathrm{bc}} \pm 0.28$ \\
\hline L.pentosus S42 & $2.42^{\mathrm{h}} \pm 0.22$ & $3.22^{\mathrm{i}} \pm 0.29$ & $3.62^{\mathrm{hi}} \pm 0.32$ & $96.77^{\mathrm{ab}} \pm 2.05$ & $83.46^{\mathrm{de}} \pm 2.84$ & $77.32^{\mathrm{gh}} \pm 1.63$ & $64.40^{1 \mathrm{ijj}} \pm 2.89$ \\
\hline L. plantarum S46 & $1.98^{\mathrm{i}} \pm 0.07$ & $2.72^{\mathrm{j}} \pm 0.10$ & $2.97^{\mathrm{j}} \pm 0.11$ & $95.65^{\mathrm{abc}} \pm 3.47$ & $94.59^{\mathrm{ab}} \pm 3.43$ & $88.41^{\mathrm{b}} \pm 3.21$ & $82.23^{\mathrm{bc}} \pm 1.49$ \\
\hline L. plantarum S49 & $4.08^{\mathrm{b}} \pm 0.07$ & $6.36^{\mathrm{b}} \pm 0.11$ & $7.23^{\mathrm{bc}} \pm 0.13$ & $90.13^{\mathrm{d}} \pm 1.60$ & $84.99^{\mathrm{d}} \pm 1.51$ & $80.50^{\mathrm{ef}} \pm 1.43$ & $77.94^{\mathrm{de}} \pm 0.69$ \\
\hline L. plantarum S61 & $3.49^{\mathrm{d}} \pm 0.04$ & $6.29^{\mathrm{b}} \pm 0.07$ & $7.16^{\mathrm{c}} \pm 0.08$ & $86.15^{\mathrm{e}} \pm 0.92$ & $79.17^{\mathrm{fg}} \pm 0.85$ & $68.69^{\mathrm{i}} \pm 0.74$ & $65.78^{\mathrm{hij}} \pm 0.35$ \\
\hline L. plantarum S62 & $3.44^{\mathrm{d}} \pm 0.10$ & $5.93^{\mathrm{c}} \pm 0.18$ & $6.10^{\mathrm{e}} \pm 0.18$ & $79.36^{\mathrm{f}} \pm 2.39$ & $78.83^{\mathrm{fg}} \pm 2.38$ & $75.86^{\mathrm{h}} \pm 2.29$ & $69.94^{\mathrm{fg}} \pm 1.05$ \\
\hline L. plantarum S71 & $3.14^{\mathrm{e}} \pm 0.33$ & $4.78^{\mathrm{e}} \pm 0.51$ & $6.02^{\mathrm{e}} \pm 0.64$ & $94.52^{\mathrm{abc}} \pm 0.89$ & $93.51^{\mathrm{ab}} \pm 1.44$ & $91.68^{\mathrm{a}} \pm 1.24$ & $85.32^{\mathrm{ab}} \pm 1.27$ \\
\hline L. plantarum S72 & $4.70^{\mathrm{a}} \pm 0.14$ & $6.74^{\mathrm{a}} \pm 0.21$ & $7.61^{\mathrm{a}} \pm 0.23$ & $97.26^{\mathrm{a}} \pm 2.98$ & $95.28^{\mathrm{a}} \pm 2.92$ & $92.44^{\mathrm{a}} \pm 2.83$ & $80.80^{\mathrm{cd}} \pm 1.24$ \\
\hline
\end{tabular}

Values are mean \pm standard error of triplicates.

${ }^{a-l}$ Means in same column of each parameter with different lower case letters differed significantly $(p<0.05)$.

Table 4 Acidification activity of Lactobacillus strains obtained in MRS broth at $37^{\circ} \mathrm{C}$

\begin{tabular}{|c|c|c|c|}
\hline LAB strains & $\mathrm{Oh}$ & $12 \mathrm{~h}$ & $24 \mathrm{~h}$ \\
\hline L.brevis S14 & $6.35^{\mathrm{a}} \pm 0.07$ & $5.65^{\mathrm{bcd}} \pm 0.07$ & $4.00^{\mathrm{b}} \pm 0.00$ \\
\hline L.brevis S18 & $6.35^{\mathrm{a}} \pm 0.07$ & $5.60^{\text {bcde }} \pm 0.00$ & $3.95^{\mathrm{b}} \pm 0.07$ \\
\hline L. brevis $\mathrm{S} 27$ & $6.35^{\mathrm{a}} \pm 0.07$ & $5.30^{\mathrm{g}} \pm 0.00$ & $3.95^{\mathrm{b}} \pm 0.07$ \\
\hline L. brevis $\mathrm{S} 63$ & $6.35^{\mathrm{a}} \pm 0.07$ & $5.45^{\mathrm{efg}} \pm 0.07$ & $3.95^{\mathrm{b}} \pm 0.07$ \\
\hline L. brevis $\mathrm{S} 82$ & $6.35^{\mathrm{a}} \pm 0.07$ & $5.75^{\mathrm{b}} \pm 0.07$ & $3.90^{\mathrm{b}} \pm 0.00$ \\
\hline L.pentosus S42 & $6.35^{\mathrm{a}} \pm 0.07$ & $5.60^{\text {bcde }} \pm 0.14$ & $3.90^{\mathrm{b}} \pm 0.00$ \\
\hline L. pentosus S75 & $6.35^{\mathrm{a}} \pm 0.07$ & $5.40^{\mathrm{fg}} \pm 0.14$ & $3.95^{\mathrm{b}} \pm 0.07$ \\
\hline L. plantarum $\mathrm{S} 23$ & $6.35^{\mathrm{a}} \pm 0.07$ & $5.60^{\text {bcde }} \pm 0.14$ & $3.95^{\mathrm{b}} \pm 0.07$ \\
\hline L. plantarum S46 & $6.35^{\mathrm{a}} \pm 0.07$ & $5.50^{\mathrm{def}} \pm 0.00$ & $3.95^{\mathrm{b}} \pm 0.07$ \\
\hline L. plantarum S49 & $6.35^{\mathrm{a}} \pm 0.07$ & $5.30^{\mathrm{g}} \pm 0.00$ & $3.90^{\mathrm{b}} \pm 0.00$ \\
\hline L. plantarum S61 & $6.35^{\mathrm{a}} \pm 0.07$ & $5.55^{\text {cdef }} \pm 0.07$ & $3.90^{\mathrm{b}} \pm 0.00$ \\
\hline L. plantarum S62 & $6.35^{\mathrm{a}} \pm 0.07$ & $5.50^{\mathrm{def}} \pm 0.00$ & $3.90^{\mathrm{b}} \pm 0.00$ \\
\hline L. plantarum S71 & $6.35^{\mathrm{a}} \pm 0.07$ & $5.65^{\mathrm{bcd}} \pm 0.07$ & $3.90^{\mathrm{b}} \pm 0.00$ \\
\hline L. plantarum S72 & $6.35^{\mathrm{a}} \pm 0.07$ & $5.65^{\mathrm{bcd}} \pm 0.07$ & $3.90^{\mathrm{b}} \pm 0.00$ \\
\hline $\begin{array}{l}\text { Control (MRS } \\
\text { broth) }\end{array}$ & $6.35^{\mathrm{a}} \pm 0.07$ & $6.35^{\mathrm{a}} \pm 0.07$ & $6.35^{\mathrm{a}} \pm 0.07$ \\
\hline
\end{tabular}

Values are mean \pm standard error of triplicates.

${ }^{\mathrm{a}-\mathrm{g}}$ Means in same column of each parameter with different lower case letters differed significantly $(\mathrm{p}<0.05)$.

The $\beta$-glucosidase activity of LAB strains is associated with the production of hydroxytyrosol (Ghabbour et al., 2011), the stable antioxidant compound highly desired in foods.

The proteolytic activity of Lactobacillus strains was determined, on skim milk agar, by observing the presence of a clear zone of proteolysis around colonies. Most of the strains showed proteolytic activity, but with variable importance. Out of 14 strains, 3 L. plantarum strains (S23, S46, and S49) and 3 L. brevis (S14,
S18 and S27) and L. pentosus S42 displayed high proteolytic activity, while $L$. brevis $\mathrm{S} 82$ showed no proteolytic activity. The results of proteolytic activity are $\mathrm{pH}$ in agreement with those obtained by other authors (Peres et al., 2014, Phyu et at., 2015). Abriouel et al (2012) reported that the proteolytic activity was not detected in any of the $\triangle A B$ isolates from spanish-green table olives. While, E. $800^{\circ}$ की

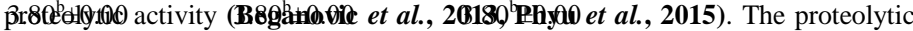

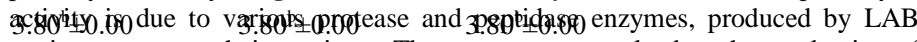
strains 0.0 procure their nutrients. These enzzomes may lead to the production of bioactive peptides, improving the functional properties of fermented products.

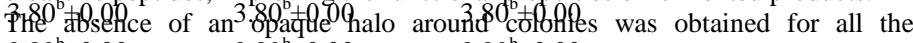

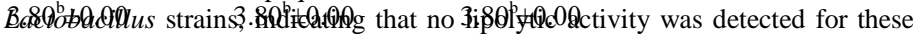

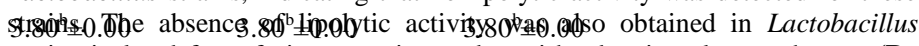
strainas disofated from fryit. Albuquerque et al., 2017, Meng et al., 2018). Generally, Lactobacillus $s p$ are considered to possess no or weak lipolytic activity (Thakkar et al., 2015).

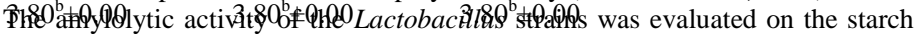

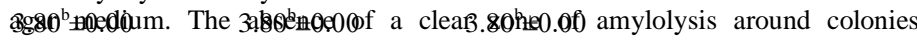

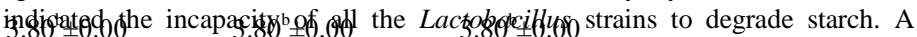
similar result of amylolytic activity was obtained in $\mathrm{LAB}$ strains originating from S.panish-green olive brines (Abriouel et at., 2012). Amylolytic LAB strains have

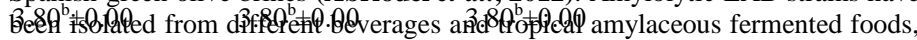

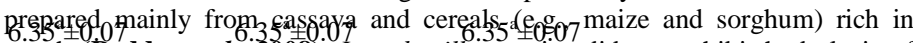
starch (Reddy et al., 2008). Lactobacillus strains did not exhibit hydrolysis of starch, this may be due to their isolation environment (olive brine) characterized by the absence of starch contents (Preedy and Watson, 2010).

The cellulolytic activity of the Lactobacillus strains was evaluated on MRS agar containing carboxymethylcellulose (CMC). The presence of a clear zone around colonies, after revelations by Congo red and $\mathrm{NaCl}$, indicated the capacity of Lactobacillus strains to degrade CMC by the production of cellulases. All of the Lactobacillus strains demonstrated high cellulolytic activity. The strains producing cellulases are good candidates in probiotic selection. Cellulases can improve the enzymatic digestion of fruits and vegetables in the gastrointestinal tract (Juturu and Wu, 2014).

Table 5 Enzymatic characterization of Lactobacillus strains

\begin{tabular}{|c|c|c|c|c|c|}
\hline LAB strains & Proteolysis $^{\mathrm{a}}$ & Lipolysis $^{\mathrm{a}}$ & Amylolysis $^{\mathrm{a}}$ & Cellulolysis $^{\mathrm{a}}$ & $\beta$-glucosidase ${ }^{\mathrm{a}}$ \\
\hline L.brevis S14 & +++ & - & - & ++ & +++ \\
\hline L.brevis S18 & +++ & - & - & ++ & +++ \\
\hline L. brevis S27 & +++ & - & - & +++ & +++ \\
\hline L. brevis $\mathrm{S} 63$ & + & - & - & ++ & +++ \\
\hline L. brevis $\mathrm{S} 82$ & - & - & - & ++ & +++ \\
\hline L.pentosus S42 & +++ & - & - & +++ & +++ \\
\hline L. pentosus S75 & ++ & - & - & +++ & +++ \\
\hline L. plantarum S23 & +++ & - & - & ++ & +++ \\
\hline L. plantarum S46 & +++ & - & - & +++ & +++ \\
\hline L. plantarum S49 & ++ & - & - & ++ & +++ \\
\hline L. plantarum S61 & + & - & - & ++ & +++ \\
\hline L. plantarum $\mathrm{S} 62$ & ++ & - & - & ++ & +++ \\
\hline L. plantarum S71 & ++ & - & - & +++ & +++ \\
\hline L. plantarum S72 & + & - & - & +++ & +++ \\
\hline
\end{tabular}




\section{CONCLUSION}

Lactic acid bacteria are the dominant microorganisms in fermenting green olives Some Lactobacillus strains, isolated from the olive brine samples, showed the high acidification and the production of flavor compounds (Diacetyl. The production of specific enzymes (i.e. $\beta$-glucosidase) showed the ability to use the Lactobacillus in production of biological table olive. The Resistance of all Lactobacillus strains to acid $\mathrm{pH}$ and Bile salt indicated their ability to survive in the gastrointestinal tract. Based the profile of technological and probiotic properties, some Lactobacillus strains can be used as the probiotic starters in different food fermentations.

Acknowledgments: The authors are grateful to the CNRST (PPR/19/2015), McGill University (Quebec), CNRST-CNR (Morocco-Italy) and Tunisian cooperation (17TM06) for their supports.

\section{REFERENCES}

ABOUlOIFA, H., ROKNI, H., BELlAOUCHI, R., GHABBOUR, N. KARBOUNE, S., BRASCA, M., BEN SALAH, R., CHIHIB, N., SAALAOUI, E. \& ASEHRAOU, A. 2019. Characterization of probiotic properties of antifungal Lactobacillus strains isolated from traditional fermenting green olives. Probiotics and Antimicrobial Proteins, 1-14. https://doi.org/10.1007/s12602019-09543-8

ABRIOUEL, H., BENOMAR, N., COBO, A., CABALLERO, N., FERNANDEZ FUENTES, M. A., PEREZ-PULIDO, R. \& GALVEZ, A. 2012. Characterization of lactic acid bacteria from naturally-fermented Manzanilla Alorena green table olives. Food microbiology, 32(2), 308-316 https://doi.org/10.1016/j.fm.2012.07.006

ARROYO-LOPEZ ， F.N., QUEROL，A., BAUTISTA-GALLEGO， J. \& GARRIDO-FERNÁNDEZ, A. 2008. Role of yeast in table olive production. International Journal of Food Microbiology, 128(2):189-196 https://doi.org/10.1016/j.ijfoodmicro.2008.08.018

ASEHRAOU, A., FAID, M. \& AKHARTOUF, R. 1993. Pure culture fermentation of green olives by lactobacilli strains. Microbiologie Aliments Nutrition, 11, 221-228.

ASEHRAOU, A., PERES, C., BRITO, D., FAID, M. \& SERHROUCHNI, M 2000. Characterization of yeast strains isolated from bloaters of fermented green table olives during storage. Grasas y Aceites, 51(4), 225-229.

BAUTISTA-GALLEGO, J., ARROYO-LOPEZ, F. N., RANTSIOU, K. JIMÉNEZ-DÍAZ, R., GARRIDO-FERNÁNDEZ, A. \& COCOLIN, L. 2013 Screening of lactic acid bacteria isolated from fermented table olives with probiotic potential. Food Research International, 50(1), 135-142. https://doi.org/10.1016/j.foodres.2012.10.004

BEGANOVIC, J., KOS, B., LEBOS PAVUNC, A., UROIC, K., DZIDARA, P. \& SUSKOVIC, J. 2013. Proteolytic activity of probiotic strain Lactobacillus $\begin{array}{llll}\text { helveticus } & \text { M92. } & \text { Anaerobe, } & \text { 58-64. }\end{array}$ https://doi.org/10.1016/j.anaerobe.2013.02.004

BEVILACQUA, A., ALTIERI, C., CORBO, M. R., SINIGAGLIA, M. \& OUOBA, L. I. 2010. Characterization of lactic acid bacteria isolated from Italian bella di cerignola table olives: selection of potential multifunctional starter cultures. Journal of food science, 75(8), M536-44. https://doi.org/10.1111/j.17503841.2010.01793.X

BONATSOU, S., TASSOU, C. C., PANAGOU, E. Z. \& NYCHAS, G. E. 2017 Table olive fermentation using starter cultures with multifunctional potential. Microorganisms, 5(2), 30. https://doi.org/10.3390/microorganisms5020030 CHUANG, L. F. \& COLLINS, E. B. 1968. Biosynthesis of diacetyl in bacteria and yeast. Journal of Bacteriology, 95(6), 2083-2089.

CIAFARDINI, G., MARSILIO, V., LANZA, B. \& POZZI, N. 1994. Hydrolysis of oleuropein by Lactobacillus plantarum strains associated with olive fermentation. Applied and Environmental Microbiology, 60(11), 4142-4147. DE ALBUQUERQUE, T. M. R., GARCIA, E. F., DE OLIVEIRA ARAUJO, A., MAGNANI, M., SAARELA, M. \& DE SOUZA, E. L. 2017. In vitro characterization of Lactobacillus strains isolated from fruit processing byproducts as potential probiotics. Probiotics and Antimicrobial Proteins. https://doi.org/10.1007/s12602-017-9318-2

DE LEONARDIS, A., TESTA, B., MACCIOLA, V., LOMBARDI, S. J. \& IORIZZO, M. 2015. Exploring enzyme and microbial technology for the preparation of green table olives. European Food Research and Technology, 242(3), 363-370. https://doi.org/10.1007/s00217-015-2546-3

DUNNEL, C., MURPHYL, L., FLYNNL, S., O'MAHONY, L., O'HALLORANL, S. \& FEENEYL, M. 1999. Probiotics: from myth to reality. Demonstration of functionality in animal models of disease and in human clinical trials. Kluwer Academic Publishers, 76, 279-292.

FERNANDEZ-DIEZ MJ, CASTRO RAMOS R, GARRIDO FERNANDEZ A HEREDIA MORENO A, MINGUEZ MOSQUERA MI, REJANO NAVARRO L, DURAN QUINTANA MC, GONZALEZ CANCHO F, GOMEZ MILLAN A GARCIA GARCIA P \& FC, S. O. 1985. Biotechnology of Table Olives. Instituto de la Grasa y sus Derivados,. Sevilla, Spain., 55-123.
FERNANDEZ, A. G., ADAMS, M. R. \& FERNANDEZ-DIEZ, M. J. 1997 Table olives : production and processing. Springer US

GHABBOUR, N., LAMZIRA, Z., THONART, P., CIDALIA, P., MARKAOUI, M. \& ASEHRAOU, A. 2011. Selection of oleuropein-degrading lactic acid bacteria strains isolated from fermenting Moroccan green olives. Grasas y Aceites, 62(1), 84-89. https://doi.org/10.3989/gya.055510

GHABBOUR, N., ROKNI, Y., LAMZIRA, Z., THONART, P., CHIHIB, N. E. PERES, C. \& ASEHRAOU, A. 2016. Controlled fermentation of Moroccan picholine green olives by oleuropein-degrading Lactobacilli strains. Grasas y Aceites, 67(2), e138. https://doi.org/10.3989/gya.0759152

GILLILAND, S. E., STALEY, T. E. \& BUSH, L. J. 1984. Importance of bile tolerance of Lactobacillus acidophilus used as a dietary adjunct. Journal of dairy science, 67(12), 3045-3051. https://doi.org/10.3168/jds.S0022-0302(84)81670-7 HICKEY, M. W., HILLIER, A. J. \& JAGO, G. R. 1983. Metabolism of pyruvate and citrate in lactobacilli. Australian journal of biological sciences, 36(5-6), 487496.

HOFMANN, A. F. \& ECKMANN, L. 2006. How bile acids confer gut mucosa protection against bacteria. Proceedings of the National Academy of Sciences 103(12), 4333-4334. https://doi.org/10.1073/pnas.0600780103

HOLZAPFEL, W. H., HABERER, P., SNEL, J., SCHILLINGER, U. \& HUIS IN'T VELD, J. H. 1998. Overview of gut flora and probiotics. International Journal of Food Microbiology, 41(2), 85-101.

HORACKOVA, S., PLOCKOVA, M. \& DEMNEROVA, K. 2018. Importance of microbial defence systems to bile salts and mechanisms of serum cholestero reduction. Biotechnology Advances, 36(3), 682-690. https://doi.org/10.1016/j.biotechadv.2017.12.005

HURTADO, A., REGUANT, C., ESTEVE-ZARZOSO, B., BORDONS, A. \& ROZĖS, N. 2008. Microbial population dynamics during the processing of Arbequina table olives. Food Research International, 41(7), 738-744 https://doi.org/10.1016/j.foodres.2008.05.007

IOOC. 2017. Key figures on the world market for table olives. http://www.internationaloliveoil.org visited at October 25th 2018.

JAY, J. M. 1982. Antimicrobial properties of diacetyl. Applied and Environmental Microbiology, 44(3), 525-532.

JUTURU, V., \& WU, J. C. 2014. Microbial cellulases: Engineering, production and applications. Renewable \& Sustainable Energy Reviews, 33, 188-203. https://doi.org/10.1016/j.rser.2014.01.077

KAILIS, S., \& HARRIS, D. J. 2007. Producing table olives. Collingwood, Victoria, Australia: Landlinks $\quad$ Press $\quad 328$ https://doi.org/10.1017/S0014479707005662

KING, N. 1948. Modifications of the Voges - Proskauer test for rapid colorimetric determination of acetylmethylcarbinol plus diacetyl in butter cultures. Dairy Industry, 13, 800 .

LUCENA-PADROS, H., CABALLERO-GUERRERO, B., MALDONADOBARRAGAN, A. \& RUIZ-BARBA, J. L. 2014. Microbial diversity and dynamics of Spanish-style green table-olive fermentations in large manufacturing companies through culture-dependent techniques. Food microbiology, 42, 154165. https://doi.org/10.1016/j.fm.2014.03.020

MARTINS, E. M. F., RAMOS, A. M., VANZELA, E. S. L., STRINGHETA, P. C., DE OLIVEIRA PINTO, C. L. \& MARTINS, J. M. 2013. Products of vegetable origin: A new alternative for the consumption of probiotic bacteria Food Research International, 51(2), 764-770. https://doi.org/10.1016/j.foodres.2013.01.047

MENG, Z., ZHANG, L., XIN, L., LIN, K., YI, H. \& HAN, X. 2018 Technological characterization of Lactobacillus in semihard artisanal goat cheeses from different Mediterranean areas for potential use as nonstarter lactic acid bacteria. Journal of dairy science, 101(4), 2887-2896. https://doi.org/10.3168/jds.2017-14003

PAN, D. D., WU, Z., PENG, T., ZENG, X. Q. \& LI, H. 2014. Volatile organic compounds profile during milk fermentation by Lactobacillus pentosus and correlations between volatiles flavor and carbohydrate metabolism. Journal of dairy science, 97(2), 624-631. https://doi.org/10.3168/jds.2013-7131

PEREIRA, A. P., PEREIRA, J. A., BENTO, A. \& ESTEVINHO, M. L. 2008 Microbiological characterization of table olives commercialized in Portugal in respect to safety aspects. Food and Chemical Toxicology, 46(8), 2895-2902. https://doi.org/10.1016/j.fct.2008.05.033

PERES, C. M., ALVES, M., HERNANDEZ-MENDOZA, A., MOREIRA, L. SILVA, S., BRONZE, M. R., VILAS-BOAS, L., PERES, C. \& MALCATA, F X. 2014. Novel isolates of lactobacilli from fermented Portuguese olive as potential probiotics. LWT-Food Science and Technology, 59(1), 234-246. https://doi.org/10.1016/j.lwt.2014.03.003

PHALAKORNKULE, C. \& TANASUPAWAT, S. 2007. Characterization of lactic acid bacteria from traditional Thai fermented sausages. Journal of Culture Collections, 5, 46-57.

PHYU, H. E. I., OO, Z. A. W. K. \& AYE, K. N. 2015. Screening on proteolytic activity of lactic acid bacteria from various yogurts and fermented milk. International Journal of Advances in Science, Engineering and Technology, 5, 34-37.

REDDY, G., ALTAF, M., NAVEENA, B. J., VENKATESHWAR, M. \& KUMAR, E. V. 2008. Amylolytic bacterial lactic acid fermentation - a review. 
Biotechnology Advances, 26(1), 22-34 https://doi.org/10.1016/j.biotechadv.2007.07.004

RINCON-DELGADILLO, M. I., LOPEZ-HERNANDEZ, A., WIJAYA, I. \&

RANKIN, S. A. 2012. Diacetyl levels and volatile profiles of commercial starter distillates and selected dairy foods. Journal of dairy science, 95(3), 11281139.https://doi.org/10.3168/jds.2011-4834

ROKNI, Y., GHABBOUR, N., CHIHIB, N. E., THONART, P. \& ASEHRAOU, A. 2015. Physico-chemical and microbiological characterization of the natural fermentation of Moroccan Picholine green olives Variety. Journal of Materials and Environmental Science, 6(6), 1740-1751.

PREEDY,V. \& WATSON, R,. 2010. Olives and olive oil in health and disease prevention. Amsterdam ; Boston : Elsevier : Academic Press pp.1479.

TANASUPAWAT, S., PHOOTTOSAVAKO, M. \& KEERATIPIBUL, S. 2015

Characterization and lipolytic activity of lactic acid bacteria isolated from Tha fermented meat. Journal of Applied Pharmaceutical Science, 5(03), 006-012. https://doi.org/10.7324/japs.2015.50302

THAKKAR, P., MODI, H. A. \& PRAJAPATI, J. B. 2015. Isolation, characterization and safety assessment of lactic acid bacterial isolates from fermented food products. International Journal of Current Microbiology and Applied Sciences, 4(4), 713-725.

TOFALO, R., PERPETUINI, G., SCHIRONE, M., CIARROCCHI, A., FASOLI, G., SUZZI, G. \& CORSETTI, A. 2014. Lactobacillus pentosus dominate spontaneous fermentation of Italian table olives. LWT - Food Science and Technology, 57(2), 710-717. https://doi.org/10.1016/j.lwt.2014.01.035

YANG, W., MENG, F., PENG, J., HAN, P., FANG, F., MA, L. \& CAO, B. 2014. Isolation and identification of a cellulolytic bacterium from the Tibetan pig's intestine and investigation of its cellulase production. Electronic Journal of Biotechnology, 17(6), 262-267. https://doi.org/10.1016/j.ejbt.2014.08.002 